\title{
EXPLORING THE LITERATURE ON CONCEPTS OF TEACHER LEADERSHIP AND TEACHER-LEADER: IS THERE A DIFFERENCE?
}

\author{
Vaida Jurgilè \\ Vytautas Magnus university, Lithuania \\ Tetiana Ponomarenko \\ Vytautas Magnus university, Lithuania \\ Lina Kaminskienè \\ Vytautas Magnus university, Lithuania \\ Vilma Žydžiūnaitè \\ Vytautas Magnus university, Lithuania
}

\begin{abstract}
The purpose of the current paper is to explore the concepts of "teacher leadership" and "teacher-leader". The current article highlights and compares the usage of the two concepts, explores the new perspectives for determination of teacher leadership within school environment. It draws from literature on teacher leadership and on-the-job leadership development to explore insights and issues on teacher leadership development, and it presents cases for theoretical determination of both concepts. The concept analysis method was implemented in order to collect the recent literature and explore the concepts of "teacher leadership" and "teacher-leader". The novelty of the current research is the definition of peculiarities in usage of both terms. The results indicate that the concept of teacher leadership is regarded as a process and activity, while the concept of teacher-leader is mostly regarded as a component of teacher's professional identity. The article concludes with implications for further theoretical research on teacher leadership.
\end{abstract}

Keywords: teacher leadership, teacher-leader, concept analysis.

\section{Introduction}

The concept of teacher leadership implies formal and informal duties, such as professional development, coordination, traineeship, head teacher, and mentor (Katzenmeyer \& Moller, 2009; Levin \& Schrum, 2016; York-Barr \& Duke, 2004). Most of studies on teacher leadership underline the need to broaden teachers' leadership roles beyond the classroom. If the teacher wants to be a leader, they must communicate with learners on multiple levels, because the teacher leader is committed to their learners' well-being both inside and outside 
the classroom. There is a need to underline the impact of teachers as an important agents of teacher leadership (Grenda \& Hackmann, 2014).

The concepts of teacher leadership and teacher-leader are being used interchangeably, as taken for granted. However, these are two distinct concepts with clear attributes and internal structures. Furthermore, the both concepts are often being used as "umbrella concepts" for related terms, such as "teacher authority", "mentorship", and "teacher agency". Therefore, the concepts of "teacher leadership" and "teacher-leader" are vague and broad and have been overused in the scientific literature. Hence, there is a need to clarify a theoretical framework of both concepts in order to promote the common understanding among scholars.

The current research is aimed to distinguish the defining attributes of two concepts "teacher leadership" and "teacher-leader". The both concepts had been broken into simpler elements in order to determine their internal structure and find interconnections. Therefore, the main research question was focused on the defining of both concepts: what main attributes of the concepts of teacher leadership/teacher-leader were defined within the recent empirical research?

\section{Methodology}

In order to answer the research questions, the research was comprised of two stages. The first stage included the systematic literature review, including literature selection, abstract review and article review. The second stage was focused on the "teacher leadership" and "teacher leader" concept analysis applying Walker and Avant (2005) methodology.

Stage 1. Conducting the literature review

The criteria of inclusion and exclusion were both inspired by pragmatical and conceptual issues related to the current research. According to Wenner and Campbell (2016), the criteria of literature selection for teacher leadership concept creation should be based on several practical criteria, which include the aspects of teacher leadership. The criteria were based on the working definition of teacher leadership, and, thus, included several principles of literature selection (Table 1).

The Tailor and Francis database was used to search for the relevant scientific literature using the defining words "teacher leadership" and "teacher-leader". The search was limited to articles published in English in a period from 2009 to 2019. The search was not limited to titles of certain publishers, specific publishing journals or geographical location. The primary search provided 362 articles for "teacher leadership" and 485 articles for "teacher-leader". 
SOCIETY. INTEGRATION. EDUCATION

Proceedings of the International Scientific Conference. Volume III, May $22^{\text {th }}-23^{\text {th }}, 2020.234-243$

Table 1 The inclusion and exclusion criteria for literature review (based on Wenner and Campbell, 2016)

\begin{tabular}{|l|l|}
\hline \multicolumn{1}{|c|}{ Inclusive criteria } & \multicolumn{1}{c|}{ Exclusive criteria } \\
\hline $\begin{array}{l}\text { Empirically based findings; literature must } \\
\text { report the findings of empirical studies }\end{array}$ & Exclude purely descriptive pieces \\
\hline $\begin{array}{l}\text { Participants are public, private school } \\
\text { teachers, who do not hold any administrative } \\
\text { positions }\end{array}$ & $\begin{array}{l}\text { Exclude studies about college-level teacher } \\
\text { leaders or preservice teachers. Exclude } \\
\text { studies about principals' or school } \\
\text { administration's leadership }\end{array}$ \\
\hline $\begin{array}{l}\text { Teachers must be employed at school at the } \\
\text { time of participation in the research; to be } \\
\text { classroom teachers (primary, secondary } \\
\text { school, subject teachers) }\end{array}$ & $\begin{array}{l}\text { Exclude studies in which participants are no } \\
\text { longer work as teachers (e.g., mentors with } \\
\text { no teaching responsibilities) }\end{array}$ \\
\hline $\begin{array}{l}\text { Teacher leadership is a subject of the study } \\
\text { Exclude studies with peripherally included } \\
\text { teacher leadership. } \\
\text { Exclude studies early childhood, pre-school, } \\
\text { vocational education }\end{array}$ \\
\hline $\begin{array}{l}\text { Articles published in the peer-reviewed } \\
\text { journals. Open access journals, full-text } \\
\text { articles. }\end{array}$ & Exclude studies without peer review \\
\hline
\end{tabular}

The next step implied the abstract review applying the inclusion/exclusion criteria, defined in the Table 1 . As a result, 765 more articles were excluded from our literature review because they did not meet one or more of our criteria. Thus, based on the abstracts reviewed, the sample of 82 pieces of literature (approximately 20\%) were included for full review, among them 45 articles for topic of "teacher leadership" and 37 for "teacher-leader".

Stage 2. Concept analysis

The concept analysis methods have few directions: concept analysis as it appears as a part of terminological analysis, concept analysis methods utilized in business studies and in nursing science (Walker \& Avant, 2005). The method of Walker and Avant (1983) is the most frequently utilized one and suitable for discussion about concepts "teacher leadership" and "teacher-leader".

Walker and Avant (2005) highlighting 6 steps of concept analysis: choose a concept, purposes of analysis, identity all other parts of concept, determine the model, borderline, case define. The concept should be attractive to the researcher or scientist, it means it should be associated with his or her work. In general, the concept analysis is aimed to recognize the peculiarities of certain concept, to make the importance of a situated concept clearly comprehensible, to enrich an existing theory and to develop a main definition (Walker \& Avant, 2005). The method concept analysis was implemented in order to explore the concepts of "teacher 
leadership" and "teacher-leader" and define the peculiarities in usage of both terms.

\section{Research results}

\section{Literature review: Attributes of teacher leadership concept}

The literature review allowed to determine the defining indications of "teacher leadership" and "teacher-leader" concepts. In general teacher leadership can be viewed from two perspectives: individual and collective. Fairman and Mackenzie (2012) view both perspectives as stages of teacher leadership, stating that it starts at the individual level and expands schoolwide. According to the authors, at the beginning, the individual teachers act as leaders in their classrooms by reviewing and reflecting on own teaching practice, experimenting and conducting research. Later they share their findings and ideas with other colleagues, collaborating and contributing to school improvement. At the latest stage of teacher leadership, the teachers (group of teachers) go beyond the school and share their ideas with a broader society of different stakeholders (Fairman \& Mackenzie, 2012). Thus, teacher leadership is can be exercised individually and collectively.

The collective view on teacher leadership rises from the distributed leadership theory and implies the notion of teacher leadership as a collective action. The number of researchers stress on the social nature of teacher leadership and its expression within the social interactions between teachers and their colleagues. Hairon, Goh, \& Chua (2015) viewed a close relationship between teacher leadership and communication within the professional learning communities in terms of building collegial relationships, enhancing teacher learning (Hairon, Goh, \& Chua, 2015), improving teaching and learning practices through discussion-based teaching (Brondyk \& Stanulis, 2014).

Defining the teacher leadership, Hairon et al (2015) give the primacy to teachers' influence on fellow teachers. Thus, "teacher leadership is the enactment of influence by teachers, individually or collectively, on school stakeholders but primarily fellow teachers towards shared goals pertaining to improvements in teaching and learning." (p.178) Therefore, the core of teacher leadership is the intentionality of impact directed towards attainment of certain common goals. The researchers state that the teacher leadership is an intentional influence of teacher leaders on fellow teachers. Their study emphasizes the interest of conceptualizing the essence of leadership as an act of influence in achieving shared goals, stating that the intentionality is a core feature of teacher leadership (Hairon et al, 2015).

Teacher leadership is regarded as an activity rather than a title (Supovitz, 2017). Teacher leadership is viewed as a day-to-day activity, more than simply a prescription of a formal role, practiced within an interaction of teacher 
leader and colleagues (Struyve, Hannes, Meredith, Vandecandelaere, Gielen, \& De Fraine, 2018). Furthermore, the activity is aimed at school or classroom change, when teacher is seen as an active agent for school change and improvement (Forde \& Dickson, 2017). Authors state that there was a shift in a paradigm of leadership from treating it as an exceptional superiority of individual leaders to the collective con-joint action, were power is exercised in different ways, depending on a context of organization (Forde \& Dickson, 2017). In addition, authors underline the reciprocal nature of the teacher leadership action, the interdependence between leaders and their followers. Liljenberg (2016) provides the similar structure of teacher leadership construct, defining three perspectives: (1) coordinating, (2) learning-enhancing and (3) change-directed.

Teacher leadership requires individuals with specific knowledge of teaching and learning, experts of teaching in certain fields, aspiring to learn and develop as professionals (Brondyk, \& Stanulis, 2014). Hairon et al. (2015) states that the positional influence (formal role) is less important than the possession of certain skills, related to facilitation, content subject, also teaching experience and coordinating the endeavors of other group members.

\section{Literature review: Attributes of teacher-leader concept}

Most of the literature related to the question "Who are teacher leaders?" specify that teacher-leaders have been teachers with important ant essential teaching experience. They are known to be great teachers and are respected among colleagues and learners.

Teacher-leaders are often classroom teachers sharing their knowledge and expertise in different ways. Danielson (2006) mentions that teacher leadership is a set of skills practiced by teachers who teach students, but their influence extends beyond their own classrooms. Sometimes teacher-leaders are formally assigned to this role and may have an officially prescribed role of teacher-leader or another position that focuses on his or her expertise, such as data coach or mentor.

Teacher-leader is considered as a role taken by the individual teacher but not an assigned position. Sherrill (1999) regards teacher-leaders as teacher educators, teachers-in-residence, master teachers, mentors and lead teachers, while Crowther et al. (2002) viewed teacher-leaders as ones, who empower the school reform. Killionand and Harrison (2006) defined ten roles of teacher leaders such as Resource Provider, Instructional Specialist, Curriculum Specialist, Classroom Supporter, Learning Facilitator, Mentor, School Leader, Data Coach and Learner.

Teachers have a better understanding of the school community needs comparing to the external experts (consultants) which can be invited to analyze and improve the school processes. In addition, external consultants and teaching experts are often lacking experience in education sphere or practice of public schools (Leana, 2013). Therefore, encouraging the local school teachers to participate in school leadership alters their perception of ownership when teachers 
become part of the decision-making process. According to Donaldson (2001), each person owns a share of influence and responsibility, not just over one's individual job, but over school-wide concerns as well.

\section{Antecedents and consequences: Teacher leadership}

Teacher leadership might occur as an outcome of teacher involvement into the research activities or inquiry of own practice, called action research (Ryan et al., 2017). Teacher leadership derives from the individual initiative of a teacher and expands to the schoolwide collective action (Fairman \& Mackenzie, 2012). Donaldson (2001) claimed about expanding teachers leadership experiences outside of the classroom as a one of school priorities in order to enable interaction among teachers and their knowledge exchange. Enabling teacher opportunities to exercise their leadership increases teacher's social capital.

Hairon et al. (2015) concluded that teacher leadership contributes to the establishment of professional learning communities by promotion of teacher learning and development, building collaborative relationships and empowering change in teaching practices of colleagues. In addition, TL enables trust, open communication and promotes an improvement within teachers' work (Hairon et al., 2015).

\section{Antecedents and consequences: Teacher-leader}

York-Barr and Duke (2004) highlight several factors which influence a teacher's preparation to accept roles and responsibilities of a teacher-leader. These factors involve teaching skills, personal educational philosophy, preparedness to share good practices with others, being interested in professional development, and having time resources to embrace the role of teacher-leader.

The individuals who work as teacher or teacher leaders at school, usually have great amount of teaching expertise. Possibilities for leadership grow out of high-level experience, because being successful maintains teachers' beliefs about their efficiency and the trust of colleagues and learners is necessary for leadership enactment (York-Barr \& Duke, 2004).

Teacher leaders are revise as achievement accepting risks and responsibility (Wilson, 1993). However, the orientation of teacher leaders does not necessarily coincide with opinions and visions of other colleagues. LeBlanc and Shelton (1997) claimed that between teachers and teacher leaders often experienced a objection because their need for attainment and need for attachment. In addition, teacher-leaders sometimes experience tensions in their relationships with colleagues (Wilson, 1993).

\section{Model and contrary cases of "teacher leadership" and "teacher-leader" concepts}

The construction of the model case requires a real-life example in order to demonstrate all possible aspects and attributes of the central concept (Walker \& Avant, 2005). These key attributes were addressed in order to seek for a real-life 
example and illustrate the notions of teacher leadership and teacher-leader. The contrary case, conversely, requires showing the opposite side of the concept, what the concept is not. The following examples were taken from the real-life experiences of Lithuanian school teachers.

\section{Model case of teacher leadership}

Jolanta had been working as a teacher at the Primary school in Kaunas city. She had about four years of teaching experience working as a classroom teacher. Jolanta noticed that the members of school staff were friendly, however, the professional communication between teachers was quite poor. Therefore, she decided to make an initiative and establish "The teacher discussion club" (as she named it). Teachers were meeting several times per week and discussing different issues related to their professional practice and improvement of student achievement and well-being at school. The meetings occurred in time free from professional duties. During the meetings all teachers were required to present and share their successful experiences in order to promote colleagues' learning. Therefore, teachers were constantly improving her expertise in order to share with other teachers. Later, teachers started to discuss not only issues related to student learning, but issues related to school development and improvement.

Thus, the teacher leadership was triggered by the intentional influence of a single teacher and later developed into a collective effort. Teacher leadership manifested through interaction between members of teacher community aimed at achievement of common aims: improvement of student and teacher learning, school improvement and development, and assurance of student and teacher wellbeing at school. The activity had a volunteering character and teachers dedicated their personal time for it; thus, teacher leadership was driven by the internal commitment of teachers. Therefore, the current model case describes the model of teacher leadership.

\section{Model case of teacher-leader}

"Teacher-dominated classroom sounds boring and bleak, but I do understand that it is less chaotic, more easily planned, assessed, and controlled. In fact, in many classrooms, there is still an old-fashioned dynamic in which the teacher's voice and opinions dominate. Sadly, in some cases, the students are taught that they are not going to be successful until they concur with the teacher."

The current case was taken from the literature. The current study, conducted by York-Barr and Duke (2004) demonstrated that teachers had high levels of instructional expertise, collaboration, reflection, and a sense of empowerment. In other words, they became teacher leaders (York-Barr \& Duke, 2004). Teachers claimed about bringing interpersonal skills and quality teaching in their classrooms. Promotion of learning among peers was also noticed by teachers.

\section{Contrary case of teacher leadership}

The teaching staff of one of the Secondary schools were required by the school administration to organize the meetings where they could discuss different professional issues. The teachers came for the first meeting and complained about how badly they are treated in the country. After they were suggested to gather one more time, most of teachers 
refused, arguing that they are lacking time for personal lives. Thus, less and less teachers were participating in the meetings, and finally, this activity failed.

Although teacher leadership manifests itself through teacher activity, however, it must be driven by teacher's inner commitment. In this case, the activity was rather driven by the external force and power exercised by the school administration. There were no clear goals and vision established for the current activity, thus, it did not become engaging and motivating. The first meeting organization was quite well; however, the clear aims and shared objectives were not set up, therefore, the further meetings remained sporadic. Teachers were not united around one shared vision of school improvement, they rather viewed their personal interests and required incentives for this kind of activity. All these attributes contrast with a notion of teacher leadership described above.

\section{Contrary case of teacher-leader}

"Sadly, in some cases, the students are taught that they are not going to be successful until they concur with the teacher. There is one right answer, one correct perspective, one way to complete a task. Do what you are told. Be what we tell you to be".

All the teacher-leader roles identified show that the function of teacherleader widely applicable and diverse. In addition, all the acknowledged roles require that the teacher-leader collaborates with others in order to share the expertise, thus applying individual expertise to develop and strengthen the social capital of teacher community. In other words, the teacher leader invests and dedicated own time and efforts in order to maintain the school community and culture and evoke improvement. However, the teacher-leader is dependent on a context he/she is working within. One can become a leader within a supportive environment where group of teachers have general goals (Dika \& Singh, 2002).

\section{Conclusions}

The conceptualization and examining of different instances of teacher leadership allowes to conclude that the core attributes of this concept are internal commitment, intentional influence and social interactions. These characteristics and cases described above, define the concept of teacher leadership and allow the broader insight into practical application of theoretical construct. Teacher leadership may be practiced collectively or individually, though it implies conjoint actions between the group of school community. The intentional nature of teacher leadership implies the establishment of common goals and shared visions among agents, and those goals are directed towards school improvement and development. While teacher-leader is often are classroom teachers who share their expertise in various forms. Teacher-leader have an influence for other teachers and develop beyond their own classrooms to others or elsewhere. Sometimes 
SOCIETY. INTEGRATION. EDUCATION

Proceedings of the International Scientific Conference. Volume III, May $22^{\text {th }}-23^{\text {th }}, 2020.234-243$

teacher-leaders are formally designated as such and may have the title of teacherleader or another title that focuses on his or her expertise, such as data coach.

\section{Acknowledgements}

The research is supported by Research Council of Lithuania, project No. PMIP-19-56, KOMOKO.

\section{References}

Brondyk, S., \& Stanulis, R. (2014). Teacher Leadership for Change. Kappa Delta Pi Record, 50(1), 13-17. DOI: 10.1080/00228958.2014.871675

Crowther, F., Kaagen, S.S., Ferguson, M., \& Si Hann, L. (2002). Developing teacher leaders: How teacher leadership enhancesschool success. Thousand Oaks, CA: Corwin Press.

Danielson, C. (2006). Teacher leadership that strengthens professional practice. Alexandria VA: ASCD.

Dika, S.L., \& Singh, K. (2002). Applications of social capital in educational literature: A critical synthesis. Review of Educational Research, 72(1), 31-60. DOI: 10.3102/ 00346543072001031.

Donaldson, L. (2001). The contingency theory of organizations. Thousand Oaks, CA: Sage.

Fairman, J.C., \& Mackenzie, S.V. (2012). Spheres of teacher leadership action for learning. Professional Development in Education, 38(2), 229-246. DOI:10.1080/194152 57.2012.657865

Forde, C., \& Dickson, B. (2017). The Place of Leadership Development for Change Agency in Teacher Education Curricula for Diversity. In L. Florian \& N. Pantić (Eds.), Teacher Education for the Changing Demographics of Schooling, Inclusive Learning and Educational Equity (pp. 83-99). Glasgow, UK: Springer International Publishing.

Hairon, S., Goh, J.W.P., \& Chua, K.C. (2015). Teacher leadership enactment in professional learning community contexts: towards a better understanding of the phenomenon. School Leadership \& Management, 35(2), 163-182. DOI:10.1080/13632434.2014.992776

Grenda, J.P., \& Hackmann, D.G. (2014). Advantages and challenges of distributing leadership in middle-level schools. NASSP Bulletin, 98(1), 53-74.

Katzenmeyer, M., \& Moller, G. (2009). Awakening the sleeping giant: Helping teachers develop as leaders (3rd ed.). Thousand Oaks, CA: Corwin Press.

Killion, J., \& Harrison, C. (2006). Taking the lead: New roles for teachers and school-based coaches. Oxford, OH: National Staff Development Council.

Leana, C. (2011). The missing link in school reform. Stanford Social Innovation Review. Retrieved from http://www.ssireview.org/articles/entry/the_missing_link_in_school_ref orm/

LeBlanc, P.R., \& Shelton, M.M. (1997). Teacher leadership: The needs of teachers. Action in Teacher Education, 19, 32-48.

Liljenberg, M. (2016). Teacher leadership modes and practices in a Swedish context - a case study. School Leadership \& Management, 36(1), 21-40. DOI: 10.1080/ 13632434.2016.116 0209. 
Ryan, M., Taylor, M., Barone, A., Della Pesca, L., Durgana, S., Ostrowski, K., Piccirillo, T., \& Pikaard, K. (2017). Teacher as Researcher, Teacher as Scholar, and Teacher as Leader. The New Educator, 13(2), 102-116. DOI: 10.1080/1547688X.2016.1144120

Sherrill, J. (1999). Preparing teachers for leadership roles in the 21st century. Theory into Practice, 38(1), 56-61. DOI:10.1080/00405849909543831.

Struyve, C., Hannes, K., Meredith, C., Vandecandelaere, M., Gielen, S., \& De Fraine, B. (2018). Teacher Leadership in Practice: Mapping the Negotiation of the Position of the Special Educational Needs Coordinator in Schools. Scandinavian Journal of Educational Research, 62(5), 701-718. DOI: 10.1080/00313831.2017.1306798

Supovitz, J.A. (2018). Teacher leaders' work with peers in a Quasi-formal teacher leadership model. School Leadership \& Management, 38(1), 53-79. DOI: 10.1080/13632434. 2017.1389718

Wilson, M. (1993). The search for teacher leaders. Educational Leadership, 50(6), 24-27.

York-Barr, J., \& Duke, K. (2004). What Do We Know about Teacher Leadership? Findings from Two Decades of Scholarship. Review of Educational Research, 74(3) 255-316. DOI: $10.3102 / 00346543074003255$ 